\title{
ENVIRONMENTAL TAXES IN NORTHERN EUROPE. THE RECENT EVOLUTION AND CURRENT STATUS IN THE BALTIC COUNTRIES
}

\author{
Dovilè Kurtinaitytè-Venediktovienè \\ Faculty of Economics and Finance Management, \\ Mykolas Romeris University \\ Ateities st. 20, LT-08303, Vilnius \\ E-mail: dovilekurtinaityte@gmail.com \\ Paulo Pereira \\ Environmental Management Centre, \\ Mykolas Romeris University \\ Ateities st. 20, LT-08303, Vilnius \\ E-mail: pereiraub@gmail.com

\section{Gediminas Černiauskas} \\ Faculty of Economics and Finance Management, \\ Mykolas Romeris University \\ Ateities st. 20, LT-08303, Vilnius \\ E-mail: gediminas.cerniauskas@sam.lt \\ Received on 19 March 2014; accepted on 30 June 2014
}

doi:10.13165/SMS-14-6-2-06

Abstract. The aim of this paper is to make a briefoverview about the recent evolution of the environmental tax systems in the Baltic region. With this purpose in mind, the article contains a review of the environmental taxes used in eight Baltic countries (Denmark, Germany, Estonia, Latvia, Lithuania, Poland, Finland and Sweden) during 
the period from 2002 till 2011. Environmental taxation evolution has taken different paths across European Union countries, underpinned by different environmental policy frameworks. Presently, the European Commission is stimulating the European Union Strategy 2020 to have a more secure and competitive green economy in Europe. The results of this paper show that the collection of environmental taxes differs among the Baltic countries. It is partly related to environmental policy of each Baltic country and partly due to environmental tax reforms, which have been implemented in Sweden, Denmark and Germany. It may also be due to more ambitious goals and purposes when it comes to reductions in energy use and to protect the nature of the world. In the article, attention is also paid to the problem of application of efficiency of economic instruments in the European Union. The authors discuss and compare environmental reflections in environmental policy of the European Union.

Keywords: environmental taxation, environmental policy, efficiency, economic instruments, Baltic countries.

\section{Introduction}

In the recent decades, the intensive use of natural resources has increased the human footprint on the earth and has been threatening the security of goods supply ${ }^{1}$. Consequently, the environment protection and management are one of the important priorities of government institutions ${ }^{2}$. All the European Union (EU), including the Baltic countries, invoke some of the economic instruments, e.g., environmental taxes, fees and charges, tradable permits, deposit-refund system and subsidies, to implement the important targets stipulated by the EU environmental policy ${ }^{3}$.

In the EU, there are several problems in order to implement the Environment Tax Reform (ETR), since many of these taxes may affect low-income households ${ }^{4}$.

1 European Commission. Communication from the Commission to the European Parliament, the Council, the European Economic and Social Committee and the Committee of the Regions. A Resource-Efficient Europe - Flagship Initiative under the Europe 2020 Strategy [interactive]. Brussels, 2011, 26. 1. 2011 COM [accessed on 2014-01-10]. <http://ec.europa.eu/resourceefficient-europe/pdf/resource_efficient_europe_en.pdf>.

2 European Commission. Tax Reforms in EU Member States 2013 of European Commission [interactive]. Brussels, 2013 [accessed on 2014-02-14]. <http://ec.europa.eu/taxation_customs/ resources/documents/taxation/gen_info/economic_analysis/tax_papers/taxation_paper_38. pdf $>$.

3 United Nations Environment Programme Environment for Development (UNEP). Economics Instruments [interactive]. 2013 [accessed on 2014-02-10]. <http://www.unep.org/regionalseas/ marinelitter/other/economics/default.asp $>$.

4 European Environment Agency. Environmental Taxes: Recent Developments in Tools for Integration [interactive]. 2010, Environmental issues series No. 18 [accessed on 2014-01-11]. $<$ http://edz.bib.uni-mannheim.de/daten/edz-bn/eua/00/envissue18.pdf $>$. 
Previous works, e.g., Symons et al. ${ }^{5}$, Barker and Köhler ${ }^{6}, \mathrm{McNally}$ and $\mathrm{Mabey}^{7}$, Ekins and Dresner ${ }^{8}$, Leipprand et al. ${ }^{9}$, Blum $^{10}$, Bach ${ }^{11}$, analyzed the distributional impact of environmental taxes in different countries of the EU (Germany, the Czech Republic, Sweden, Spain, the United Kingdom, Italy, Finland). These studies showed different results, which depend on the model used, the subject of analysis and the selected countries $^{12}$. Some EU countries have a system of policy taxation to punish or get some additional funds to invest in environmental related issues. Some of the Member States have taken actions on environmental policy taxation; however, the advance in this question is still limited. In 2012, eleven countries received recommendations regarding this question ${ }^{13}$ (France, Belgium, the Czech Republic, Italy, Estonia, Lithuania, Latvia, Austria, Hungary, Slovakia and Luxembourg).

In the Baltic countries, the most effective measure to increase efficiency and protect the natural resources is the implementation of environmental taxes. These taxes are the cost of the activities and the prices of commodities that have a negative effect on the environment. EU environmental taxes are classified in four categories: energy taxes, transport taxes, pollution and resources taxes ${ }^{14}$.The aim of this work is to accomplish the following tasks:

1. To revise the current knowledge about the impact of environmental taxes on EU Member States;

2. To determine the position of environmental taxes in the actual EU modern tax system;

3. To set general economic trends of the development of environmental taxes in the EU;

5 Symons, E.; Proops, J.; Gay, P. 1994. Carbon Taxes, Consumer Demand and Carbon Dioxide Emissions: A Simulation Analysis for the UK. Fiscal Studies. 15: 19-43.

6 Barker, T.; Köhler, J. 1998. Equity and Ecotax Reform in the EU: Achieving a 10 Per Cent Reduction CO2Emissions Using Excise Duties. Fiscal Studies. 19(4): 375-402.

7 McNally, R. H. G.; Mabey, N. 1999. The Distributional Impacts of Ecological Tax Reform. United Kingdom: WWF.

8 Ekins, P.; Dresner, S. 2004. Green Taxes and Charges: Reducing Their Impact on Low-Income Households. London: Policy Studies Institute.

9 Leipprand, A., et al. 2007. Links between the Social and Environmental Pillars of Sustainable Development. Task 1D: Environmental taxes, Ecologic.

10 Blum, U. 2008. Untere Einkommensgruppen sind an Kosten des ökologischen Umbaus der Energiewirtschaft stark überproportional beteiligt. Wirtschaft im Wandel. 6.

11 Bach, S. 2009. Zehn Jahre ökologische Steuerreform: Finanzpolitisch erfolgreich, klimapolitisch halbherzig. DIW Wochenbericht . (14): 218-227.

12 Supra note 4.

13 Supra note 2.

14 European Commission. Regressivity of Environmental Taxation: Myth or Reality? [interactive]. Brussels, 2012, Nr. 32-2012 [accessed on 2014-02-14]. <http://ec.europa.eu/taxation_customs/ resources/documents/taxation/gen_info/economic_analysis/tax_papers/taxation_paper_32_ en.pdf $>$. 
4. To study the recent evolution and current status of environmental taxes in the Baltic countries.

\section{The environmental effectiveness of taxes and their economic and social impact. The environmental taxes evolution}

Economic instruments, including taxation policy, may help policy makers to meet environmental targets in the EU. The efficiency of economic instruments depends on the selected instruments ${ }^{15}$. According to Costantini and Mazzanti ${ }^{16}$, the $\mathrm{EU}$ is the world leader in the projection, admission and implementation of strict environmental policies. From this position, many concerns have emerged about the unfavorable effects of the ETR and climate actions on employment, income distribution, economic growth and exportations. Together with other North European countries (Denmark, Finland, Norway and the Netherlands), Sweden was the first one to implement the ETR in the early 1990s. The main purpose was to stimulate employment. The main principle of these reforms was to reduce taxes on labour ${ }^{17}$. Few years after this, the first ETR were implemented in European countries. The first environmental fiscal reform was implemented on April 1, 1999. Further steps of this reform were implemented from 2000 till 2003. In Germany, the major objective of the environmental fiscal reform was to reduce energy consumption and the consequent emissions, to promote the development of new technologies and to invest in innovations. The revenues from those taxes were used to reduce pension insurance contributions ${ }^{18}$. It also created an important meaningful number of jobs (approximately 250000 in 2003), about $0.75 \%{ }^{19}$.

The efficiency of the environmental taxes depends on several components, tax base, the tax rate, evolution of the tax, tax policy. The design of the environmental taxes (i.e., its tax rate applied, point of application and breadth of coverage) and their implementation are variable among EU states. The ETR differences among states are specially related with the approach. Some states focus on a narrower set of tax

15 Fullerton, D.; Leicester, A.; Smith, S. 2010. Environmental Taxes. Oxford: Oxford University Press.

16 Costantini, V.; Mazzanti, M. 2012. On the Green and Innovative Side of Trade Competitiveness? The Impact of Environmental Policies and Innovation on EU Exports. Elsevier Research Policy. 41: $132-153$.

17 Heine, D.; Norregaard, J.; Parry, W.H. International Monetary Fund Working Paper. Environmental Tax Reform: Principles from Theory and Practice to Date [interactive]. 2012 [accessed on 2014-02-10]. <http://www.imf.org/external/pubs/ft/wp/2012/wp12180.pdf>.

18 Bach, S., et al. 2002. The Effects of Environmental Fiscal Reform in Germany: A Simulation Study. Elsevier Energy Policy. 30(9): 803-811.

19 European Environment Agency. Environmental Tax Reform in Europe: Implications for Income Distribution [interactive]. 2011, Technical report No. 16/2011 [accessed on 2013-12-20]. $<$ http://www.eea.europa.eu/publications/environmental-tax-reform-in-europe/>. 
base, while others adopt a much wider approach ${ }^{20}$. For example, the majority of the EU countries apply vehicle taxes, one of the most important environmental policy instruments to achieve climate policy targets. Lithuania and Estonia are the only two countries that do not apply vehicle taxes. Poland and Bulgaria use vehicle taxes, but without $\mathrm{CO}_{2}$ and fuel-efficiency differentiation. Hence, according to the European Commission (EC), these four countries could expand their tax bases, involving vehicle into their tax systems. It could help them to reduce transport-related $\mathrm{CO}_{2}$ emissions ${ }^{21}$.

The same environmental and $\mathrm{CO}_{2}$ tax rates should be applied for all tax payers and for all energy products to assure the effectiveness of the economic sector. Nevertheless, practice is different from academic models. Nowadays, environmental tax rates applied differ substantially in all countries of the EU, showing that there is no harmonization ${ }^{22}$.

The evolution of the taxes is one of the most important issues in order to assess the efficiency of environmental policies. Figure 1 shows the development of environmental taxes in the last four decades in the EU. User fees and earmarked charges prevailed in the middle of the20th century of the early environmental policy. In 1990-2000, the focus was directed to fiscal environmental taxes and ecological tax reforms (environmental tax reforms of the Nordic countries and others). The main aim of the activities of green commissions (e.g., The Dutch Green Tax Commission, 1995 and the Green Fiscal Commission, 2007) was to promote public and political discussions on environmental and economic significance, also to use communication activities to develop consciousness and comprehension of the selections for environmental tax reforms. Hence, green tax commissions have played a supportive role in many states ${ }^{23}$. From 2010, the emphasis has shifted to the Europe 2020 strategy. The main objective of the Europe 2020 strategy is to involve together the economic, social and environmental agendas of the $\mathrm{EU}$ in a more successive mode.

The strategy is based on five targets:

- An employment rate of $75 \%$ of the working age population;

- $3 \%$ of the EU's GDP should be invested in research and innovation;

- 20/20/20 climate and energy targets (the reduction of greenhouse gas emissions by at least $20 \%$, a share of final energy consumption coming from renewable energy sources increased to $20 \%$, and an energy sufficiency of $20 \%)$;

20 Institute for European Environmental Policy (IEEP). Final Report. Evaluation of Environmental Tax Reforms: International Experiences [interactive]. 2013 [accessed on 2014-02-01]. <http:// www.efv.admin.ch/e/downloads/finanzpolitik_grundlagen/els/IEEP_2013_e.pdf>.

21 Supra note 14

22 Supra note 19.

23 European Environment Agency. Environmental Taxes: Recent Developments in Tools for Integration [interactive]. 2010, Environmental issues series No. 18 [accessed on 2014-01-11]. $<$ http://edz.bib.uni-mannheim.de/daten/edz-bn/eua/00/envissue18.pdf >. 
- The improvement of education levels (reduction of school drop-out rates and an increased share of the population having completed tertiary or equivalent education);

- The promotion of social inclusion, including the reduction of poverty ${ }^{24}$.

Figure 1. Chronological evolution of environmental taxes

User charges

Earmarked charges

Fiscal environmental taxes

Ecological taxes reforms

Green tax commissions

The European Union 2020 Strategy

$$
\begin{array}{llll}
1970 & 1980 \quad 1990 \quad 2000
\end{array}
$$

2020

Sources: own elaboration based on data from the European Environment Agency (2000)

\section{Comparison of environmental taxation by the type:}

Economic assessment of energy taxes, transport taxes and pollution/resources taxes in the Baltic countries

The EU is the first and only region, which requires energy taxation from all the Member States. As a result of this requirement, all European countries use taxes on multifarious energy commodities. The most significant energy products for transport purposes are petrol and diesel. Energy products for stationary use involve fuel oils, natural gas, coal and electricity. Usually, the basic objective of the environmental taxes (also energy taxes) is to gather revenue for the public sector. Detailed figures of energy taxes by the Baltic countries are represented in Table 1a.

Table 1a. Values of energy taxes. Unit: millions of euro

\begin{tabular}{|l|c|c|c|c|c|c|c|c|c|c|c|c|}
\hline Country & 2002 & 2003 & 2004 & 2005 & 2006 & 2007 & 2008 & 2009 & 2010 & 2011 & Total & Average \\
\hline Denmark & 4800 & 4907 & 4958 & 4871 & 4855 & 4872 & 4923 & 4885 & 5341 & 5610 & 50022 & 5002 \\
\hline Germany $^{*}$ & 46389 & 50009 & 48271 & 46459 & 46772 & 45275 & 45678 & 45944 & 45769 & 47556 & 468122 & 46812 \\
\hline Estonia & 117 & 134 & 174 & 215 & 241 & 290 & 318 & 353 & 374 & 391 & 2606 & 261 \\
\hline Latvia & 174 & 197 & 238 & 291 & 320 & 362 & 383 & 380 & 359 & 391 & 3094 & 309 \\
\hline Lithuania & 303 & 329 & 333 & 364 & 394 & 459 & 498 & 513 & 492 & 497 & 4183 & 418 \\
\hline Poland & 4197 & 4044 & 4328 & 5548 & 6168 & 7124 & 7945 & 6547 & 7644 & 7963 & 61508 & 6151 \\
\hline
\end{tabular}

24 Council of the European Union. Strategy for Employment and Growth [interactive]. 2010 [accessed on 2014-01-30]. <http://www.consilium.europa.eu/homepage/showfocus?lang=en\& focusID $=65890>$. 


\begin{tabular}{|l|c|c|c|c|c|c|c|c|c|c|c|c|}
\hline Finland & 2854 & 2882 & 2956 & 2927 & 2986 & 2961 & 3215 & 3102 & 3222 & 3928 & 31033 & 3103 \\
\hline Sweden & 6519 & 6872 & 7024 & 7108 & 7237 & 7318 & 7189 & 6636 & 7719 & 7855 & 71477 & 7148 \\
\hline Total & $\mathbf{6 5 3 5 4}$ & $\mathbf{6 9 3 7 4}$ & $\mathbf{6 8 2 8 1}$ & $\mathbf{6 7 ~ 7 8 3}$ & $\mathbf{6 8 9 7 2}$ & $\mathbf{6 8 6 6 1}$ & $\mathbf{7 0 ~ 1 4 9}$ & $\mathbf{6 8 3 5 9}$ & $\mathbf{7 0 ~ 9 2 1}$ & $\mathbf{7 4 ~ 1 9 1}$ & $\mathbf{6 9 2 0 4 5}$ & $\mathbf{6 9 2 0 5}$ \\
\hline Average & $\mathbf{8 1 6 9}$ & $\mathbf{8 6 7 2}$ & $\mathbf{8 5 3 5}$ & $\mathbf{8 4 7 3}$ & $\mathbf{8 6 2 2}$ & $\mathbf{8 5 8 3}$ & $\mathbf{8 7 6 9}$ & $\mathbf{8 5 4 5}$ & $\mathbf{8 ~ 8 6 5}$ & $\mathbf{9 2 7 4}$ & $\mathbf{8 6 5 0 6}$ & $\mathbf{8 6 5 1}$ \\
\hline
\end{tabular}

* until 1990 the former territory of the FRG

Sources: own elaboration based on data from Eurostat (2013)

Undoubtedly, environmental tax levels across the Baltic region vary a lot. The Energy Tax Directive confers for lower EU minimum levels of taxation (expressed in $€$ per 1000 liter) for diesel than for petrol. During almost the ten-year period from 2002 till 2011, the highest values of energy taxes were found in Germany (468 122 million euro), followed by Sweden (71 477 million euro), Poland (61 508 million euro), Denmark (50 022 million euro) and Finland (31 033 million euro), while the lowest values of energy taxes were found in Estonia (2606 million euro), followed by Latvia (3094 million euro) and Lithuania (4183 million euro). In terms of the collection of environmental taxes, Germany is one of the leaders in the Baltic region. Environmental taxes were firmly enlarged till 2003 as a result of ecological tax reform in Germany, which came into force in 1999. In the following years, nevertheless, their revenue decreased again to 2,3\% of GDP in 2011. Germany has the highest rates of taxation, with $€ 58 / \mathrm{tCO} 2$ for electricity and $€ 27.4 / \mathrm{tCO} 2$ for natural gas. This large difference exists partly because of the EU ETS component of $€ 11.7 / \mathrm{tCO} 2$ on electricity, but also because the excise tax is 70 percent higher on electricity $€ 46.5 /$ tCO2 than $€ 27.4 / \mathrm{tCO} 2$ on gas ${ }^{25}$.

A few economic instruments, such as energy taxation and environmentallymotivated energy taxation schemes, exist in the Nordic countries (Sweden, Finland, Denmark and Norway). These economic instruments address to solve the environmental problems in all European countries ${ }^{26}$. The data provided by the Eurostat shows that the highest shares of energy taxes in the total tax revenues after Germany and Poland are also found in Sweden, Denmark and Finland. There is an interesting fact that all of the Nordic countries display a substantially lower share of energy taxes in the total tax revenues than in Poland, one of the biggest states in Central Europe. The government of Poland is increasing progressively the excise duty rates on tobacco products (by $4 \%$ a year), also for fuels (jet engine fuels, diesel and intrinsic bio-components). According to the Energy Directive, as of 2012 the excise tax is also applicable to coal, lignite and coke, so far exempted.

25 Vivid Economics. Carbon Taxation and Fiscal Consolidation: The Potential of Carbon Pricing to Reduce Europe's Fiscal Deficits, Report Prepared for the European Climate Foundation and Green Budget Europe [interactive]. 2012 [accessed on 2014-02-11]. <http://www. vivideconomics.com/uploads/reports/fiscal-consolidation-and-carbon-fiscal-measures/ Carbon_taxation_and_fiscal_consolidation.pdf $>$.

26 Ptak, M, 2010. Environmentally Motivated Energy Taxes in Scandinavian Countries. Economic and Environmental Studies. 10(3): 255-269. 
Ultimately, a new tax on extraction of certain minerals, such as copper and silver, has been introduced ${ }^{27}$. The analyzed countries average for the value of energy taxes increased in 2011, compared with the last year, even though in all examined states there have been average's fluctuations during the period from 2002 till 2011 (Table 1a). Comparing the data with the last two years, some countries have increased their tax on diesel more than their tax on petrol, videlicet Poland, Denmark and Finland. According to the European Commission, the general essential advancement still needs to be made and the preferential tax treatment of diesel, especially in Lithuania, Germany, Finland and other European countries, such as Belgium, Greece, France, Portugal, Luxembourg, the Netherlands, Slovenia, Slovakia, to be revised ${ }^{28}$. Coherent and neutral taxation of all transport fuels is relevant with a view of providing proper stimulus for the swaddling of carbon- and energy-efficient fuel technologies without favoring specific fuels or technologies ${ }^{29}$.

Today, EU Member States still have unequally established policies towards the taxation of transport, related to heritage of historical, social and economic motives and causes. Separate European countries apply different rules of own national legislation. The differences of attitudes to the taxation of transport perforce lead to different costs in each country of the Baltic region for fuel and vehicles ${ }^{30}$. For example, there are still a few countries (Lithuania and Estonia) that do not apply any vehicle taxes, even though the International Monetary Fund (hereinafter referred to as the IMF) has repeatedly recommended that Lithuania and Estonia introduce taxes on vehicles. Nowadays, the government of Lithuania considers introducing tax on vehicles, which comes into force from October 2014. Revenues from vehicle taxes can be used not only to increase revenue in the budget, but also to reduce the pollution in Lithuania. In Poland, tax rates vary depending on the total weight of vehicle, and Poland applies one of these taxes, but without $\mathrm{CO} 2$ or fuel-efficiency differentiation ${ }^{31}$. Consequently, in Table 1b, during the period from 2002 till 2011 the lowest values of transport taxes were found in Estonia ( 80 million euro), Latvia (505 million euro) and Lithuania (582 million euro), while the highest values of transport taxes were found in Germany (84 129 million euro), followed by Denmark (40 129 million euro), Finland (17 154 million euro), Sweden (13 301 million euro) and Poland (6 783 million euro).

There are two basic modes of transport taxes, which are applied in EU countries:

- Registration taxes charged on purchase of the car;

- Circulation taxes charged yearly on car possession.

\section{Supra note 2.}

Some of these states are already taxing diesel at relatively high rates in level terms. Supra note 14.

Swedish Environmental Protection Agency. EU - Fuel and Vehicle Tax Policy [interactive]. Sweden, Naturvårdsverkets reprocentral, 2000 [accessed on 2014-02-03]. <http://www.ieep. eu/assets/190/EUfuelandvehicletax.pdf $>$.

31 Supra note 14. 
Table $1 b$. Values of transport taxes. Unit: millions of euro

\begin{tabular}{|l|c|c|c|c|c|c|c|c|c|c|c|c|}
\hline Country & 2002 & 2003 & 2004 & 2005 & 2006 & 2007 & 2008 & 2009 & 2010 & 2011 & Total & Average \\
\hline Denmark & 3487 & 3304 & 3951 & 4570 & 4946 & 5024 & 4318 & 3352 & 3601 & 3575 & 40129 & 4013 \\
\hline Germany & 7600 & 7340 & 7740 & 8680 & 8940 & 8910 & 8840 & 8200 & 8490 & 9389 & 84129 & 8413 \\
\hline Estonia & 15 & 4 & 7 & 8 & 9 & 9 & 7 & 6 & 7 & 10 & 80 & 8 \\
\hline Latvia & 35 & 36 & 40 & 40 & 49 & 60 & 53 & 41 & 61 & 91 & 505 & 50 \\
\hline Lithuania & 111 & 122 & 143 & 100 & 23 & 30 & 15 & 12 & 13 & 14 & 582 & 58 \\
\hline Poland & 511 & 416 & 696 & 691 & 636 & 740 & 911 & 707 & 754 & 721 & 6783 & 678 \\
\hline Finland & 1474 & 1693 & 1893 & 1829 & 1890 & 1847 & 1674 & 1359 & 1650 & 1845 & 17154 & 1715 \\
\hline Sweden & 890 & 913 & 962 & 1182 & 1267 & 1415 & 1669 & 1542 & 1720 & 1741 & 13301 & 1330 \\
\hline Total & $\mathbf{1 4 ~ 1 2 4}$ & $\mathbf{1 3 ~ 8 2 7}$ & $\mathbf{1 5 4 3 1}$ & $\mathbf{1 7} \mathbf{1 0 0}$ & $\mathbf{1 7 7 6 0}$ & $\mathbf{1 8 0 3 4}$ & $\mathbf{1 7 4 8 6}$ & $\mathbf{1 5 2 1 9}$ & $\mathbf{1 6 2 9 5}$ & $\mathbf{1 7 3 8 6}$ & $\mathbf{1 6 2} \mathbf{6 6 2}$ & $\mathbf{1 6 2 6 6}$ \\
\hline Average & $\mathbf{1 7 6 6}$ & $\mathbf{1 7 2 8}$ & $\mathbf{1 9 2 9}$ & $\mathbf{2 1 3 7}$ & $\mathbf{2 2 2 0}$ & $\mathbf{2 2 5 4}$ & $\mathbf{2 1 8 6}$ & $\mathbf{1 9 0 2}$ & $\mathbf{2 0 3 7}$ & $\mathbf{2 ~ 1 7 3}$ & $\mathbf{2 0 3 3 3}$ & $\mathbf{2 0 3 3}$ \\
\hline
\end{tabular}

* until 1990 the former territory of the FRG

Sources: own elaboration based on data from Eurostat (2013)

Since 2000, many European countries, e.g., Germany, Sweden and Denmark, have reformed their environmental tax system related to taxes directly to $\mathrm{CO} 2$ emissions rates of the vehicles. Germany, which had formerly taxed vehicles mainly grounded on engine size, changed to the linear tax in July 2009. In October 2006, Sweden modified from a weight-based circulation tax to a linear CO2-based tax. In both countries, the tax differs greatly across vehicles; for instance, in both countries, the tax for a gasoline vehicle with $250 \mathrm{~g} \mathrm{CO} 2 / \mathrm{km}$ is more than twice as high as the tax for a vehicle with $150 \mathrm{~g} \mathrm{CO} 2 / \mathrm{km}$ (45 mpg). According to Klier and Linn (2012), these changes give the possibility to investigate the efficiency of such policies and to evaluate the alteration in manufacturers' profits from reducing emissions rates ${ }^{32}$.

Table $2 \mathrm{a}$ presents the data about pollution and resources taxes revenues in the eight analyzed countries in the period of 2002-2011 (the total revenue from pollution/ resources taxes is 17946 million euro across all the Baltic region countries). The data provided by Eurostat show that the highest values of pollution/resources taxes were found in Denmark (6 168 million euro) and Poland (4 854 million euro), followed by Germany ( 3080 million euro) and Sweden ( 2150 million euro). However, the lowest values of pollution/resources taxes were found in Latvia (149 million euro) and Lithuania (154 million euro), followed by Estonia (404 million euro) and Finland (986 million euro). Comparing the data in Table 2a with other categories of environmental taxes (energy and transport taxes), it can be asserted that pollution/

32 Klier, T.; Linn, J. MIT Center for Energy and Environmental Policy Research. CEEPR WP 2012-2011. Using Vehicle Taxes to Reduce Carbon Dioxide Emissions Rates of New Passenger Vehicles: Evidence from France, Germany, and Sweden [interactive]. 2012 [accessed on 201402-01]. <http://web.mit.edu/ceepr/www/publications/workingpapers/2012-011.pdf>. 
resource taxes represented a relatively small share of the total environmental taxes. In many of the Baltic region countries, the transport industry paid less than $10 \%$ of pollution taxes. In 2011, the most important exceptions to this were Lithuania and Romania, where the transport industry alone paid $14 \%$ and $20 \%$ of pollution taxes, respectively ${ }^{33}$.

Table 2a. Values of taxes on pollution/resources. Unit: millions of euro

\begin{tabular}{|l|c|c|c|c|c|c|c|c|c|c|c|c|}
\hline Country & 2002 & 2003 & 2004 & 2005 & 2006 & 2007 & 2008 & 2009 & 2010 & 2011 & Total & Average \\
\hline Denmark & 641 & 623 & 627 & 630 & 648 & 676 & 666 & 599 & 504 & 554 & 6168 & 617 \\
\hline Germany & 20 & 20 & 20 & 20 & 20 & 20 & 20 & 1100 & 410 & 1430 & 3080 & 308 \\
\hline Estonia & 23 & 27 & 23 & 32 & 44 & 55 & 55 & 54 & 45 & 49 & 404 & 40 \\
\hline Latvia & 19 & 16 & 13 & 15 & 16 & 15 & 14 & 11 & 13 & 16 & 149 & 15 \\
\hline Lithuania & 12 & 11 & 16 & 17 & 17 & 18 & 21 & 18 & 7 & 16 & 154 & 15 \\
\hline Poland & 286 & 221 & 235 & 210 & 658 & 443 & 573 & 690 & 762 & 775 & 4854 & 485 \\
\hline Finland & 61 & 73 & 75 & 105 & 117 & 126 & 103 & 92 & 103 & 131 & 986 & 99 \\
\hline Sweden & 278 & 287 & 269 & 254 & 245 & 230 & 179 & 128 & 136 & 144 & 2150 & 215 \\
\hline Total & $\mathbf{1 3 4 0}$ & $\mathbf{1 2 7 7}$ & $\mathbf{1 2 7 7}$ & $\mathbf{1 2 8 4}$ & $\mathbf{1 7 6 5}$ & $\mathbf{1 5 8 3}$ & $\mathbf{1 6 3 1}$ & $\mathbf{2 6 9 2}$ & $\mathbf{1 9 8 1}$ & $\mathbf{3 1 1 5}$ & $\mathbf{1 7 9 4 6}$ & $\mathbf{2 2 4}$ \\
\hline Average & $\mathbf{1 6 8}$ & $\mathbf{1 6 0}$ & $\mathbf{1 6 0}$ & $\mathbf{1 6 0}$ & $\mathbf{2 2 1}$ & $\mathbf{1 9 8}$ & $\mathbf{2 0 4}$ & $\mathbf{3 3 7}$ & $\mathbf{2 4 8}$ & $\mathbf{3 8 9}$ & $\mathbf{2 2 4 3}$ & $\mathbf{2 2 4}$ \\
\hline
\end{tabular}

* until 1990 the former territory of the FRG

Sources: own elaboration based on data from Eurostat (2013)

In Lithuania, pollution tax was legalized by the Pollution Tax Act ${ }^{34}$ in 1999. This tax not only has been imposed on sources of pollution pernicious to the environment, but also revenues gained from it serve for financing of protection of the environment ${ }^{35}$.

Therefore, in 2011, Latvia re-introduced excises on natural gas, extended the vehicle tax burden on luxury, environmentally unfriendly and powerful cars, and in 2012 the government of Latvia widened the tax base by including certain lubricating oil groups ${ }^{36}$. According to Eurostat data, it can be seen that pollution/resource tax revenues from 2002 till the economic crisis of 2009 were increasing in many countries of the Baltic region (Table 2a). Most of the pollution tax revenues collected by governments were paid by the private sector in many EU countries. Among businesses, the highest share of pollution taxes was paid by services (other than

33 Eurostat Statistical Books, Eurostat Yearbook 2012. Europe in Figures [interactive]. 2012, ISSN 1681-4789 [accessed on 2014-01-10]. <http://epp.eurostat.ec.europa.eu/cache/ITY_OFFPUB/ KS-CD-12-001/EN/KS-CD-12-001-EN.PDF>

34 The Law on Pollution Tax of the Republic of Lithuania. Official Gazette. 1999, No. 47-1469.

35 Dybiec, K. 2013. Greening Polish and Lithuanian Tax Systems. Social Transformations in Contemporary Society. Vilnius, p. 173-184. 
transport, storage and communication) and by mining, manufacturing, electricity supply and construction; these two activity groupings contributed by $32.0 \%$ and $31.5 \%$ of the total revenue in the EU (Eurostat Yearbook, 2012). In Table 2a, it can be seen that in 2010 a slight increase of pollution/resource tax revenues was found in most of the analyzed countries. The data for resource taxes are quite restricted. On average, among the EU countries for which the data exist, households paid $37 \%$ of the resource tax revenues collected by governments. Exceptions are Lithuania, Portugal, Sweden and the UK, where apart of households is very small. In these countries, mining and quarrying as well as water supply, sewerage and waste management paid a large part of the resource tax revenues ${ }^{37}$.

\section{Environmental tax collection in eight Baltic countries during 2002-2011}

Table $2 b$. Values of total environmental taxes. Unit: millions of euro

\begin{tabular}{|l|c|c|c|c|c|c|c|c|c|c|c|c|}
\hline Country & 2002 & 2003 & 2004 & 2005 & 2006 & 2007 & 2008 & 2009 & 2010 & 2011 & Total & Average \\
\hline Denmark & 8929 & 8834 & 9535 & 10071 & 10449 & 10573 & 9907 & 8836 & 9446 & 9739 & 96319 & 9632 \\
\hline Estonia & 154 & 164 & 204 & 255 & 293 & 353 & 379 & 413 & 426 & 449 & 3091 & 309 \\
\hline Finland & 4389 & 4648 & 4924 & 4861 & 4993 & 4934 & 4992 & 4553 & 4975 & 5904 & 49173 & 4917 \\
\hline Germany & 54009 & 57369 & 56031 & 55159 & 55732 & 54205 & 54538 & 55244 & 54669 & 58375 & 555331 & 55533 \\
\hline Latvia & 228 & 249 & 291 & 346 & 385 & 437 & 449 & 432 & 433 & 498 & 3749 & 375 \\
\hline Lithuania & 426 & 462 & 492 & 482 & 433 & 508 & 534 & 543 & 512 & 528 & 4918 & 492 \\
\hline Poland & 4995 & 4681 & 5258 & 6449 & 7462 & 8307 & 9429 & 7944 & 9161 & 9459 & 73144 & 7314 \\
\hline Sweden & 7688 & 8072 & 8255 & 8544 & 8749 & 8962 & 9038 & 8306 & 9575 & 9740 & 86928 & 8693 \\
\hline Total & $\mathbf{8 0 ~ 8 1 8}$ & $\mathbf{8 4 4 7 8}$ & $\mathbf{8 4 9 9 0}$ & $\mathbf{8 6 ~ 1 6 6}$ & $\mathbf{8 8 4 9 8}$ & $\mathbf{8 8 2 7 9}$ & $\mathbf{8 9 2 6 6}$ & $\mathbf{8 6 2 7 0}$ & $\mathbf{8 9 1 9 7}$ & $\mathbf{9 4 6 9 2}$ & $\mathbf{8 7 2} \mathbf{6 5 3}$ & $\mathbf{8 7 2 6 5}$ \\
\hline Average & $\mathbf{1 0 ~ 1 0 2}$ & $\mathbf{1 0 5 6 0}$ & $\mathbf{1 0 6 2 4}$ & $\mathbf{1 0 7 7 1}$ & $\mathbf{1 1 0 6 2}$ & $\mathbf{1 1 0 3 5}$ & $\mathbf{1 1 ~ 1 5 8}$ & $\mathbf{1 0 7 8 4}$ & $\mathbf{1 1} \mathbf{1 5 0}$ & $\mathbf{1 1} \mathbf{8 3 7}$ & $\mathbf{1 0 9} \mathbf{0 8 2}$ & $\mathbf{1 0 ~ 9 0 8}$ \\
\hline
\end{tabular}

* until 1990 the former territory of the FR

Sources: own elaboration based on data from Eurostat (2013)

The insights made in this analysis showed that from 2010 the environmental tax system has been improving in many Baltic region countries. To summarize the intermittent data in Table $2 b$, it can be stated that revenues from environmental taxes will increase in all countries of the Baltic region till 2020. Positive growing trends are based on some changes of environmental policies, which have been made in the EU countries by national governments during the period from 1999 till 2013. Particularly, it should be emphasized that one of the leaders of the Baltic region 
is Germany. In the 2002-2011 period, the value of total environmental taxes was 555331 million euro. Recently, Germany has introduced a tax on nuclear fuel and a duty on airline tickets for planes leaving from domestic airports. The rates of tax depend on the flight distance: $€ 8$ for short-distance flights, $€ 25$ for medium-distance flights and $€ 45$ for long-distance flights. According to the data from the European Commission, in Germany environmental taxes were firmly enlarged in the 19992003 period as a result of the environmental tax reform (from a pre-reform level of $2.1 \%$ of GDP to $2.7 \%$ in 2003). In the following years, their revenue decreased again to $2.3 \%$ of GDP (in 2011), which was fractionally below the EU average (2.4\%). In Table $2 \mathrm{~b}$, it can be seen that Denmark is also a particularly strong country of its high level of environmental taxation. In 2011, environmental taxes created $4.1 \%$ of GDP, not far to the values for the past few years but slightly below the medium of the period 2000-2007. However, Danish environmental tax system remains to have the highest level in the EU. This mirrors a versatile and ambitious energy tax system, in which all energy projects and design of energy taxation are applied to both energy and $\mathrm{CO} 2$ taxes. In addition, there are invoked a broad diapason of other taxes collected on environmentally noxious materials and products and a meaningful car registration tax. Following this, augmentations in Danish environmental taxation are planned gradually in the period of 2010-2019. In comparison with other analyzed countries, Swedish environmental taxation system is lower than in Germany or Denmark, but in general Swedish taxation levels are the second highest in the EU, after Denmark. Environmental taxes as a ratio of GDP (2.5\% in 2011) correspond to the average of the EU (2.4\%). Their level of environmental taxation was steady enough during the period under consideration. Considering EU Member States, revenues from environmental taxes were lower; however, they remained alike steady (5.7\% in 2011) and were comprised mainly of energy taxes ${ }^{38}$.

Table $2 \mathrm{~b}$ presents the collection of environmental taxes in the 2002-2011 period in Poland. The coefficient of environmental taxation to GDP was on a slithering up trend since 1995 and peaked in 2006-2007 to $2.7 \%$ and then remained at $2.6 \%$ level during 2008 and 2011, which keeps at fractionally (0.2\%) more than the medium value in the EU. Compared to Germany, Denmark and Sweden, Poland takes the fourth position according to the value of total environmental taxes. Nevertheless, it should be mentioned that Finland was outdistanced by Poland in terms of the collection of environmental taxes (Table 2b). In Finland, environmental tax revenues consisted of 3.1\% of GDP in 2011 and rather exceeded the EU medium level (2.4\%) and were the fifth highest in all the EU. The level of energy taxation in ratio to GDP (2.1\%) was also more than the EU average in 2011 (1.8\%), while that of transport taxes

38 European Commission, Eurostat Statistical Books. Taxation and Customs Union. Taxation Trends in the European Union. Data for the EU Member States, Iceland and Norway [interactive]. Brussels, 2013, ISSN 1831-8789 [accessed on 2014-01-13]. <http://epp.eurostat. ec.europa.eu/cache/ITY_OFFPUB/KS-DU-11-001/EN/KS-DU-11-001-EN.PDF>. 
(transport fuel excluded 1.0\%, the EU 27 average $0.5 \%$ ) was higher due to relatively heavy vehicle taxation in Finland. In 2012, the rates of excise duty on petrol and diesel were increased by $4 \%$ and $6 \%$ respectively, corresponding to the increase of $\mathrm{CO} 2$ component of energy taxation from EUR 50/tCO2 to EUR 60/tCO2. Finland also applies a tax on newly registered cars and an annual circulation tax. This is a modern vehicle tax system, when scale of both taxes is dependent on the $\mathrm{CO} 2$ emissions of the $\mathrm{car}^{39}$.

In terms of economic growing indicators, during the previous decades Lithuania was a hegemonic country between Latvia and Estonia. Compared to the two other Baltic countries, Lithuania (4918 million euro) is the leader according to the value of total environmental taxes (during the 2002-2011 period), followed by Latvia ( 3 749 million euro) and Estonia (3 091 million euro) (Table 2b). In Latvia, since 2008 the revenue from environmental taxes has increased and created $2.5 \%$ of GDP in 2011 in the same range with the European average and consisted mostly of energy taxes levied on transport fuel. Meanwhile, in Estonia revenue from environmental taxes formed $8.6 \%$ of total taxation in 2011, it was several points above the European average. A part of environmental tax revenues shows a constantly growing trend from 1995 further on, mirroring partly the necessity to adjust the excise duties up to the EU minimal rates, however, also a measured policy of the government to fund the cuts of personal income taxes by increases in consumption and environmental taxation. After some meaningful policy reforms in 2006, 2008 and 2009, Lithuania also presented some environmental policy changes during 2011 (Eurostat, 2013). For instance, in Lithuania, the excise duty on gas oil used a motor fuel was increased by more than $10 \%$, from $€ 274.27$ to $€ 302.07$ per 1000 liters, with effect from January 1 , 2011, which created $0.1 \%$ of GDP (European Commission, 2012). Likewise, according to Eurostat data, in Lithuania pollution tax is applied on emissions from stationary and mobile sources, certain goods, as well as packaging. The rate depends on the specific pollution-related indicators established by country institution $s^{40}$.

The performed analysis shows that environmental taxation, particularly on energy and transport, has trends to rise upward in the period of 2009-2020, and the main motivation for this trend is new challenges and modern priorities of environmental policy of the European Union Member States.

\section{Conclusions}

Undoubtedly, a part of environmental taxes in the total tax revenue is gradually increasing in the Baltic region. It can be argued that the environmental tax system is 
one of the relevant political modes to achieve policy objectives and benefits, such as economic inducement to reduce pollution, protect land and reduce resources use ${ }^{41}$.

The analysis of environmental taxation in eight analyzed countries of the Baltic region in the period of 2002-2011 leads to the following conclusions:

Germany, Denmark and Sweden stand out as the lead countries based on their experience with environmental tax reforms and provide an important lesson for other Baltic region states. As a result, in terms of the collection of revenue from environmental taxes, these countries have had the highest level of environmental taxation during the last decades (2002-2011).

The analysis shows that the revenue collected from pollution and resources taxes is certainly slight to the revenue collected from energy taxes and transport taxes, which is obviously prevailing in this aspect in all Baltic region.

It can be assumed that the revenues from environmental taxes will increase in all the countries of the Baltic region till 2020. Positive growing trends are based on alterations of environmental policies, which have been made in the Baltic countries by national governments during the period from 1999 till 2013.

An ongoing process of greening national tax systems can be observed in all the European Union. Therefore, political improvements of environmental tax systems give a relevant and strong motive for the sustainable development in the global economy. Certainly, the evolution of environmental taxes is based on historical heritage of the European Union and economic aspects, such as the level of economic development, the size of the state and population. Relating to European Union requests in the field of environmental and climate protection and also because of the steady development and growing of standard of living, which environment is a part of, the procedure is anticipated to be continued in all the states of the European Union.

\section{References}

Bach, S., et al. 2002. The Effects of Environmental Fiscal Reform in Germany: A Simulation Study. Elsevier Energy Policy. 30(9): 803-811.

Bach, S. 2009. Zehn Jahre ökologische Steuerreform: Finanzpolitisch erfolgreich, klimapolitisch halbherzig. DIW Wochenbericht . (14): 218-227.
Barker, T.; Köhler, J. 1998. Equity and Ecotax Reform in the EU: Achieving a 10 Per Cent Reduction CO2Emissions Using Excise Duties. Fiscal Studies. 19(4): 375-402.

Blum,U.2008.UntereEinkommensgruppen sind an Kosten des ökologischen Umbaus der Energiewirtschaft stark

41 European Environment Agency. Environmental Tax Reform in Europe: Implications for Income Distribution [interactive]. 2011, Technical report No. 16/2011 [accessed on 2013-12-20]. $<$ http://www.eea.europa.eu/publications/environmental-tax-reform-in-europe/>. 
überproportional beteiligt. Wirtschaft im Wandel. 6.

Costantini, V.; Mazzanti, M. 2012. On the Green and Innovative Side of Trade Competitiveness? The Impact of Environmental Policies and Innovation on EU Exports. Elsevier Research Policy. 41: 132-153.

Council of the European Union. Strategy for Employment and Growth [interactive]. 2010 [accessed on 201401-30]. <http://www.consilium. europa.eu/homepage/showfocus?lang $=$ en $\&$ focusID $=65890>$.

Dybiec, K. 2013. Greening Polish and Lithuanian Tax Systems. Social Transformations in Contemporary Society. Vilnius, p. 173-184.

Ekins, P.; Dresner, S. 2004. Green Taxes and Charges: Reducing Their Impact on Low-Income Households. London: Policy Studies Institute.

European Environment Agency. Environmental Taxes: Recent Developments in Tools for Integration [interactive]. 2010, Environmental issues series No. 18 [accessed on 201401-11]. <http://edz.bib.uni-mannheim. de/daten/edz-bn/eua/00/envissue18. pdf $>$.

European Environment Agency. Environmental Tax Reform in Europe: Implications for Income Distribution [interactive]. 2011, Technical report No. 16/2011 [accessed on 201312-20]. <http://www.eea.europa. $\mathrm{eu} /$ publications/environmental-taxreform-in-europe/>.

European Commission. Communication from the Commission to the European Parliament, the Council, the European Economic and Social Committee and the Committee of the Regions. A Resource-Efficient Europe - Flagship Initiative under the Europe 2020 Strategy [interactive]. Brussels, 2011,
26. 1. 2011 COM [accessed on 201401-10]. <http://ec.europa.eu/resourceefficient-europe/pdf/resource_ efficient_europe_en.pdf $>$.

European Commission. Regressivity of Environmental Taxation: Myth or Reality? [interactive]. Brussels, 2012, Nr. 32-2012 [accessed on 2014-02-14]. $<$ http://ec.europa.eu/taxation_customs/ resources/documents/taxation/gen_ info/economic_analysis/tax_papers/ taxation_paper_32_en.pdf $>$.

European Commission. Tax Reforms in EU Member States. Tax Policy Challenges for Economic Growth and Fiscal Sustainability [interactive]. Brussels, 2012, Working paper No. 34-2012, 06/2012 [accessed on 2014-02-14]. $<$ http://ec.europa.eu/taxation_customs/ resources/documents/taxation/gen_ info/economic_analysis/tax_papers/ taxation_paper_34_en.pdf>.

European Commission. Tax Reforms in EU Member States 2013 of European Commission [interactive]. Brussels, 2013 [accessed on 2014-02-14]. <http:// ec.europa.eu/taxation_customs/ resources/documents/taxation/gen_ info/economic_analysis/tax_papers/ taxation_paper_38.pdf $>$.

European Commission. Environmental Taxes - Revised Statistical Guide [interactive]. Brussels, 2013, ISSN 2315-0815 [accessed on 2014-02-14]. <http://epp.eurostat.ec.europa.eu/ cache/ITY_OFFPUB/KS-GQ-13-005/ EN/KS-GQ-13-005-EN.PDF>.

Eurostat Statistical Books, Eurostat Yearbook 2012. Europe in Figures [interactive]. 2012, ISSN 1681-4789 [accessed on 2014-01-10]. <http:// epp.eurostat.ec.europa.eu/cache/ITY_ OFFPUB/KS-CD-12-001/EN/KS-CD12-001-EN.PDF $>$. 
Fullerton, D.; Leicester, A.; Smith, S. 2010. Environmental Taxes. Oxford: Oxford University Press.

Heine, D.; Norregaard, J.; Parry, W.H. International Monetary Fund Working Paper. Environmental Tax Reform: Principles from Theory and Practice to Date [interactive]. 2012 [accessed on 2014-02-10]. <http://www.imf.org/ external/pubs/ft/wp/2012/wp12180. pdf $>$.

Institute for European Environmental Policy (IEEP). Final Report. Evaluation of Environmental Tax Reforms: International Experiences [interactive]. 2013 [accessed on 201402-01]. <http://www.efv.admin.ch/e/ downloads/finanzpolitik_grundlagen/ els/IEEP_2013_e.pdf $>$.

Klier, T.; Linn, J. MIT Center for Energy and Environmental Policy Research. CEEPR WP 2012-2011. Using Vehicle Taxes to Reduce Carbon Dioxide Emissions Rates of New Passenger Vehicles: Evidence from France, Germany, and Sweden [interactive]. 2012 [accessed on 2014-02-01]. <http:// web.mit.edu/ceepr/www/publications/ workingpapers/2012-011.pdf $>$.

Leipprand, A., et al. 2007. Links between the Social and Environmental Pillars of Sustainable Development. Task 1D: Environmental taxes, Ecologic.

McNally, R. H. G.; Mabey, N. 1999. The Distributional Impacts of Ecological Tax Reform. United Kingdom: WWF.

Ptak, M, 2010. Environmentally Motivated Energy Taxes in Scandi- navian Countries. Economic and Environmental Studies. 10(3): 255-269.

Swedish Environmental Protection Agency. EU - Fuel and Vehicle Tax Policy [interactive]. Sweden, Naturvårdsverkets reprocentral, 2000 [accessed on 2014-02-03]. <http://www.ieep.eu/assets/190/ EUfuelandvehicletax.pdf $>$.

Symons, E.; Proops, J.; Gay, P. 1994. Carbon Taxes, Consumer Demand and Carbon Dioxide Emissions: A Simulation Analysis for the UK. Fiscal Studies. 15: 19-43.

The Law on Pollution Tax of the Republic of Lithuania. Official Gazette. 1999, No. 47-1469.

United Nations Environment Programme Environment for Development (UNEP). Economics Instruments [interactive]. 2013 [accessed on 2014-02-10]. <http://www.unep. org/regionalseas/marinelitter/other/ economics/default.asp $>$.

Vivid Economics. Carbon Taxation and Fiscal Consolidation: The Potential of Carbon Pricing to Reduce Europe's Fiscal Deficits, Report Prepared for the European Climate Foundation and Green Budget Europe [interactive]. 2012 [accessed on 2014-02-11]. <http://www.vivideconomics.com/ uploads/reports/fiscal-consolidationand-carbon-fiscal-measures/Carbon_ taxation_and_fiscal_consolidation. pdf>. 


\title{
APLINKOS APSAUGOS MOKESČIAI ŠIAURĖS EUROPOJE. NAUJAUSI POKYČIAI IR DABARTINĖS PADE்TIES VERTINIMAS BALTIJOS ŠALIŲ REGIONE
}

\author{
Dovilè Kurtinaitytè-Venediktovienè, Paulo Pereira, Gediminas Černiauskas \\ Mykolo Romerio universitetas, Lietuva
}

Santrauka. Pagrindinis straipsnio tikslas yra atlikti trumpa mokslinę naujausiu aplinkos apsaugos mokesčiu sistemos pokyčių Baltijos šaliu regione apžvalgą. Šiuo tikslu straipsnio autoriai pasirinko aštuonias Baltijos regiono šalis (Daniją, Vokietija, Estija, Latvija, Lietuvą, Lenkiją, Suomiją ir Švedija) ir analizavo 2001-2012 m. laikotarpi. Per ši laikotarpi Europos Sajungos aplinkos apsaugos mokesčių srityje ivyko ryškių pokyčių. Pastaruoju metu Europos Komisija strategija „Europa 2020“ skatina igyvendinti saugesnę ir konkurencingesnę žaliają ekonomika Europoje. Tyrimo rezultatai parode, kad aplinkos mokesčiu surinkimas Baltijos šaliu regione skiriasi. To priežastys yra susisijusios su taikoma aplinkos mokesčiu politika Baltijos šalių regione ir, žinoma, igyvendintomis aplinkos mokesčiu reformomis Švedijoje, Danijoje ir Vokietijoje. Aplinkos apsaugos mokesčių surinkimo skirtumus gali lemti ir nevienodos šalių ambicijos sumažinti energijos vartojima ir apsaugoti pasaulio gamtą. Analizuojamas efektyviu ekonominiu priemoniu taikymas ir jo rezultatai Europos Sajungos politikos kontekste.

Reikšminiai žodžiai: aplinkos apsaugos mokesčiai, aplinkos apsaugos politika, efektyvumas, ekonominès priemonès, Baltijos regiono šalys.

Dovilè Kurtinaitytė-Venediktovienė, Mykolo Romerio universitetas, doktorantè. Mokslinių tyrimų kryptys: aplinkos apsaugos ekonomika, tiesioginiai ir netiesioginiai mokesčiai, mokesčių teisè, finansų teisè.

Dovilè Kurtinaitytė-Venediktovienè, Mykolas Romeris University, Doctoral Student. Research interests: Environmental Economics, Direct and Indirect Taxes, Tax Law, Finance Law.

Paulo Pereira, Mykolo Romerio universiteto Aplinkos valdymo centro profesorius. Mokslinių tyrimų kryptys: darnus vystymasis, žemėnaudos pokyčiai, dirvožemio tyrimai, aplinkosaugos supratimas, gaisrų poveikis ekosistemoms.

Paulo Pereira, Environmental Management Centre, Mykolas Romeris University, Professor. Research interests: Sustainable Development, Land use change, Soil Science, Environmental Perception, Fire Impact in the Ecosystems. 
Gedinimas Černiauskas, Mykolo Romerio universiteto profesorius, daktaras. Mokslinių tyrimų kryptys: mikroekonomika, makroekonomika, ekonominių teorijų istorija, sveikatos ekonomika.

Gediminas Černiauskas, Mykolas Romeris University, Professor dr. Research Interests: Microeconomics, Macroeconomics, History of Economic Theory, Health Economics. 